\title{
At-Turats
}

Jurnal Pemikiran Pendidikan Islam

journal homepage: http://jurnaliainpontianak.or.id/index.php/atturats

\section{PERAN AJARAN TASAWUF SEBAGAI PSIKOTERAPI MENGATASI KONFLIK BATIN}

\author{
Waslah \\ Fakultas Agama Islam (FAI) \\ Universitas KH. A. Wahab Hasbullah \\ (UNWAHA) Tambakberas Jombang \\ waslahstaibu@gmail.com
}

\begin{abstract}
A B S T R A C T
Amid the crises of life which is too materialistic, secular as well as a very hard life, economically and psychologically, Sufism provides the antidote spiritual, which gives resilience to the crisis of spirituality modern which has resulted in them no longer know who he is meaning and purpose of life on earth. The lack of clarity on the meaning and purpose of life, eventually resulted in a prolonged agony. The purpose of this study to determine the type - the type of inner conflict can be resolved with psychotherapy mysticism, Sufism as describe the role of psychotherapy in overcoming inner conflicts, and to describe the implementation of Sufism as psychotherapy in overcoming inner conflicts. This research includes the study of literature and when viewed in terms of closers including qualitative research because the data presented in the form of a statement-pernyataan.Untuk answer psychological problems, Sufism teaches about a happy life. Happy life should be alive and well both physically and mentally. Live happily with the inner conflict will never be obtained. This is because the happiness that is created will throw the whole mind - pikran inner nature.
\end{abstract}

Keywords: Mysticism, Psychotherapy, Inner Conflict

\section{PENDAHULUAN}

Globalisasi seperti sekarang ini perubahan yang terjadi diberbagai aspek begitu cepat dan pasti yang menuntut setiap individu untuk dapat beradaptasi dan mengikuti setiap perubahan yang terjadi, Padahal dalam kenyataannya tidak semua individu mampu melakukannya sehingga yang terjadi justru masyarakat atau manusia menghadapi banyak problem. Tidak semua orang mampu untuk beradaptasi, akibatnya adalah individu-individu yang menyimpan berbagai problem psikis dan fisik yang otomatis menimbulkan konflik batin dalam diri mereka, dengan demikian dibutuhkan cara efektif untuk mengata-sinya.

Proses modernisasi yang makin meluas di abad modern kini telah mengantarkan hidup manusia menjadi lebih materealistik dan individualis. Perkembangan industrialisasi dan ekonomi yang demikian pesat, telah menempatkan manusia modern ini menjadi manusia yang tidak lagi memiliki pribadi yang merdeka, hidup mereka sudah diatur oleh otomatisasi mesin yang serba mekanis, sehingga kegiatan sehari-hari pun sudah terjebak oleh alur rutinitas yang menjemukan. Akibatnya manusia sudah tidak acuh lagi, terhadap agama dan peran agama menjadi kian tergeser oleh kepentingan materi duniawi.

Selain itu, masyarakat di era globalisasi ini juga sangat mendewa-dewakan ilmu pengetahuan dan teknologi, sementara pemahaman keagamaan yang didasarkan wahyu di tinggalkan dan hidup dalam keadaan sekuler. Mereka cenderung mengejar kehidupan materi dan bergaya 
hidup hedonis dari pada memikirkan agama yang dianggap tidak memberikan peran apapun masyarakat demikian telah kehilangan visi ke-Ilahian yang tumpul penglihatannya terhadap realitas hidup dan kehidupan. Kemajuan-kemajuan yang terjadi telah merambah dalam berbagai aspek kehidupan, baik sosial, ekonomi budaya dan politik. Kondisi ini sedikit banyak telah mempengaruhi mental masyarakat sehingga yang terjadi justru masyarakat atau manusia yang menyimpan banyak problem. Krisis jiwa (mental) yang menimpa manusia, biasanya sebagai akibat dari terhalangnya seseorang dari apa yang di inginkan oleh salah satu motifnya yang kuat, atau lemahnya krisis mental dipengaruhi oleh kondisi sosial dan moral dirinya sendiri. Orang akan menjadi sasaran kegalauan psikologis dan fisik, jika ia tidak mampu mengatasi krisis psikologis dengan cara yang cepat dan tepat.

Ditengah berbagai krisis kehidupan yang serba materialis, sekular serta kehidupan yang sangat sulit secara ekonomi maupun psikologis, tasawuf memberikan obat penawar rohani, yang memberi daya tahan terhadap krisis kerohanian modern yang telah mengakibatkan mereka tidak lagi mengenal siapa dirinya arti dan tujuan dari kehidupan di dunia. Ketidakjelasan atas makna dan tujuan hidup ini, pada akhirnya membuahkan penderitaan batin yang berkepanjangan. Maka kemudian mata air yang sejuk memberikan penyegaran serta menyelamatkan pada manusia yang terangsang itu, dalam wacana kontemporer disebut sebagai terapi tasawuf. Sesungguhnya agama merupakan terapi bagi penyakit jiwa atau mental. Sebab ia bisa mengubah, memperbarui, dan memperbaiki jiwa. Agama juga memberi kekuatan penuh kepada manusia ketika ia berhadapan dengan kebimbangan keputusasaan dan agama memberi sifat kesabaran ketika manusia dilanda frustasi

${ }^{1}$ M. Amin Syukur, Tasawuf Kontekstual Solusi Problem Manusia Modern (Yogyakarta: Pustaka, 2003), 112. dan memberi ketenteraman ketika manusia ketakutan dan bahaya. Hanya melalui Aqidah dan keimanan jiwa akan hidup dan akal akan selamat.

Kecenderungan masyarakat untuk mengikuti kegiatan-kegiatan spiritual (tasawuf) kini mulai semakin banyak muncul. Tasawuf sebagai inti ajaran Islam muncul dengan memberi solusi dan terapi bagi problem manusia dengan cara mendekatkan diri kepada Allah yang Maha Pencipta. Selain itu berkembang pula kegiatan konseling dan psikoterapi yang memang bertujuan membantu seseorang menyelesaikan masalah. Karena semua masalah pasti ada penyelesaiannya serta segala penyakit pasti ada obatnya. Peluang tasawuf dalam menangani penyakitpenyakit psikologis atas segala problem manusia, semakin terbentang lebar di era global ini.

Tasawuf pada dasarnya merupakan jalan atau cara yang ditempuh oleh seseorang untuk mengetahui tingkah laku nafsu dan sifat-sifat nafsu, baik yang buruk maupun yang terpuji. Karena itu kedudukan tasawuf dalam Islam diakui sebagai ilmu agama yang berkaitan dengan aspek-aspek moral serta tingkah laku yang merupakan substansi Islam. Dimana secara filsafat sufisme itu lahir dari salah satu komponen dasar agama Islam, yaitu Iman, Islam dan Ihsan. Kalau iman melahirkan ilmu teologi (kalam), Islam melahirkan ilmu syari'at, maka ihsan melahirkan ilmu akhlaq atau tasawuf. ${ }^{1}$

Meskipun dalam ilmu pengetahuan wacana tasawuf tidak diakui karena sifatnya yang Adi Kodrati - namun eksistensinya di tengah-tengah masyarakat membuktikan bahwa tasawuf adalah bagian tersendiri dari suatu kehidupan masyarakat; sebagai sebuah pergerakan, keyakinan, agama organisasi, jaringan bahkan penyembuhan atau terapi. ${ }^{2}$

${ }^{2}$ Moh Soleh, Agama Sebagai Terapi (Yogyakarta: Pustaka Pelajar, 2005), 35. 
Tasawuf atau sufisme diakui dalam sejarah telah berpengaruh besar atas kehidupan moral dan spiritual Islam sepanjang ribuan tahun yang silam. Selama kurun waktu itu tasawuf begitu lekat dengan dinamika kehidupan masyarakat luas, bukan sebatas kelompok kecil yang eksklusif dan terisolasi dari dunia luar, akan tetapi kehadiran tasawuf di dunia modern ini sangat diperlukan, guna membimbing manusia agar tetap merindukan Tuhannya, dan bisa juga untuk menarik orang-orang yang semula hidupnya glamour dan suka hura-hura menjadi orang yang asketis (Zuhud pada dunia).

Omar Alishah dalam bukunya "Tasawuf Sebagai Terapi" menawarkan cara Islami dalam pengobatan gangguan kejiwaan yang dialami manusia, yaitu dengan cara melalui terapi sufi. Terapi tasawuf bukanlah bermaksud mengubah posisi maupun menggantikan terapi yang selama ini di dominasi oleh medis, justru cara terapi sufi ini memiliki karakter dan fungsi melengkapi. Karena terapi tasawuf merupakan terapi pengobatan yang bersifat alternatif. Tradisi terapi di dunia sufi sangatlah khas dan unik. Ia telah dipraktekkan selama berabad-abad lamanya, namun anehnya baru di zamanzaman sekarang ini menarik perhatian luas baik di kalangan medis pada umumnya, maupun kalangan terapis umum pada khususnya. Karena menurut Omar Alisyah, terapi sufi adalah cara yang tidak bisa diremehkan begitu saja dalam dunia terapi dan penanganan penyakit (gangguan jiwa), ia adalah sebuah alternatif yang sangat penting. ${ }^{3}$

Dengan demikian, terapi tasawuf atau sering juga disebut dengan penyembuhan sufis adalah penyembuhan cara islami yang

\footnotetext{
${ }^{3}$ Omar Alishah, Tasawuf sebagai Terapi (Bandung: Pustaka Hidayah, 2002), 5.

${ }^{4}$ Amin Annajar, Psikoterapi Sufistik dalam Kehidupan Modern (Bandung: Mizan Media Utam, 2004), 195.

${ }^{5}$ Isep Zainal Arifin, Bimbingan Penyuluhan Islam, Pengembangan Dakwah Melalui Psikoterapi
}

dipraktekkan oleh para sufi ratusan tahun lalu. Prinsip dasar penyembuhan ini adalah bahwa kesembuhan hanya datang dari Allah Yang Maha Penyembuh, sedangkan para sufi sebagai terapis hanya bertindak sebagai perantara. $^{4}$

Terapi Tasawuf ini dapat disebut juga terapi psikospiritual atau psikoreligius atau religio psychotherapy. Religio psychotherapy ${ }^{5}$ cenderung disebut sebagai psikoterapi religius yaitu penyembuhan penyakit melalui hidup kejiwaan yang didasari pada nilai keagamaan, tetapi tidak bermaksud mengubah keimanan dan kepercayaan pasien melainkan membangkitkan kekuatan batin pasien untuk membantu proses penyembuhan bersama-sama terapi lainnya.

\section{HASIL DAN PEMBAHASAN}

a. Jenis - Jenis Konflik Batin yang Dapat Diatasi dengan Psikoterapi Tasawuf

Dalam kegiatan keseharian, orang banyak mengaitkan tasawuf dengan unsur kejiwaan dalam diri manusia.Hal ini cukup beralasan, mengingat dalam substansi pembahasannya, tasawuf selalu membicarakan persoalan persoalan yang berkisar pada jiwa manusia. ${ }^{6}$ Hanya saja, dalam jiwa yang dimaksud adalah jiwa manusia muslim, yang tentunya tidak lepas dari sentuhan - sentuhan keislaman. Dari sinilah, tasawuf terlihat identik dengan unsurkejiwaan manusia muslim. Konfliek merupakan percekcokan, perselisihan atau pertentangan antar umat manusia.

Adapun macam-macam penyakit (gangguan) jiwa sangat banyak. Menurut Dadang Hawari, gangguan atau penyakit

Islam (Jakarta: PT. Raja Grafindo Persada, 2009), 240-244.

${ }^{6}$ Prof. Dr. M. Solihin M.Ag dan Prof Dr. Rosihon Anwar, M.Ag., Ilmu Tasawuf, (Bandung: Pustaka Setia, 2008), 104 
jiwa yang sering terjadi di masyarakat secara umum adalah sebagai berikut: ${ }^{7}$

1. Fobia, yaitu rasa takut yang tidak rasional dan tidak realistis. Pengidapnya tahu dan sadar benar akan ketidakrasionalan dan ketidakbenarannya, tetapi ia tidak mampu mencegah dan mengendalikan diri dari rasa takut tersebut.

2. Obsesi, yaitu corak pikiran yang sifatnya terpaku (persistent) dan berulang kali muncul. Orang yang mengalami gangguan ini tahu akan kelainan pikirannya itu,tetapiia tidak mampu mengalihkan pikirannya ke masalah lain dan tidak mampu mencegah munculnya pikiran tersebut yang selalu muncul berulang-ulang.

3. Kompulsi, yaitu pola perbuatan yang diulang-ulang. Pengidapnya paham benar bahwa perbuatan mengulangulang itu tidak benar dan tidak rasional,tetapi ia tidak mampu mencegah perbuatannya sendiri

Selain tiga gangguan jiwa tersebut, masalah jiwa lainnya yang sering terjadi pada manusia menurut psikologi islam adalah sebagai berikut:

- Riya'. Penyakit ini mengandung tipuan. Sebab, orang yang berbuat riya' mengatakan atau melakukan perbuatan yang tidak sesuai dengan hakikat sebenarnya.

- Iri dan dengki, yaitu sikap yang melahirkan sakit hati jika orang lain mendapat kesenangan dan kemuliaan, serta menginginkan kesenangan dan kemuliaan itu hilang dari orang tersebut dan beralih kepada dirinya.

- Rakus, yaitu ingin memperoleh lebih banyak dari yang diperlukan.

- Waswas. Penyakit ini akibat bisikan hati, cita-cita, dan angan-angan dalam nafsu dan kelezatan

\footnotetext{
${ }^{7}$ Dadang Hawari, Al-Qur'an Ilmu Kedokteran Jiwa dan Kesehatan Jiwa (Yogyakarta: Bina Bhakti Prima Yasa, 1995), hlm. 253
}

- Berbicara berlebihan. Keinginan berbicara banyak merupakan salah satu kualitas manusia yang paling merusak. Hal tersebut bisa menimbulkan pembicaraan yang tidak berguna dan berbohong8

b. Peranan Tasawuf sebagai Psikoterapi dalam Mengatasi Konflik Batin

Dalam pembahasan tasawuf dibicarakan tentang hubungan jiwa dengan badan.Yang dikehendaki dari uraian tentang hubungan antara jiwa dan badan dalam tasawuf adalah terciptanya keserasian antara keduanya. Pembahasan tentang jiwa dan badan ini dikonsepsikan para sufi dalam rangka melihat sejauh mana hubungan perilaku yang dipraktekkan manusia dengan dorongan yang dimunculkan dengan dimunculkan jiwanya sehingga perbuatan itu dapat terjadi. Dari sini, baru muncul kategori - kategori perbuatan manusia, apakah dikategorikan sebagai perbuatan jelek atau perbuatan baik. Jika perbuatan yang ditampilkan seseorang, ia disebut sebagai orang berahlaq baik. Sebaliknya, jika perbuatan yang ditampilkan jelek, ia disebut orang yang berakhlak jelek.

Dalam pandangan kaum sufi, akhlak dan sifat seseorang bergantung pada jenis jiwa yang berkuasa atas dirinya. Jika yang berkuasa dalam tubuhnya adalah nafsu - nafsu hewani atau nabati pula, yang akan tampil dalam perilakunya adalah perilaku insan pula.

Dalam masyarakat belakangan ini, istilah mental dinilai tidak asing lagi. Orang - orang sudah dapat menilai apakah seseorang itu baik mentalnya maupun tidak. Di dalam ilmu psikoterapi, kata "mental" sering digunakan sebagai nama lain dari "personality" (kepribadian yang berarti

${ }^{8}$ Hasan Langgulung, Teori-Teori Kesehatan Mental (Jakarta: Pustaka al-Husna, 1986), hlm. 328 
bahwa mental adalah semua unsur jiwa termasuk pikiran, emosi, sikap/

Attitude, dan perasaan yang dalam keseluruhan dan kebulatannya akan menentukan corak laku, cara menghadapi suatu hal yang menekankan perasaan, mengecewakan atau menggembirakan, menyenangkan dan lain sebagainya. $^{9}$

Permasalahan mental merupakan salah satu dari sekian banyak permasalahan yang menarik perhatian para ahli psikologi, terutama ahli psikologi yang berada di negara negara maju, sehingga mereka telah dapat melakukan penelitian - penelitian ilmiah yang menghubungkan antara kelakuan dan keadaan mental.Hasil dari penelitian tersebut yakni manusia terdiri dari dua golongan menurut kondisi mentalnya yakni orang yang sehat mentalnya dan orang yang sakit mentalnya.Orang ang sehat mentalnya adalah orang yang mampu merasakan kebahagiaan dalam hidup, karena pada dasarnya orang - orang inilah yang dapat merasakan bahwa dirinya berhargadan mampu menggunakan segala potensi dan bakatnya semaksimal mungkin dengan cara yang membawa kebahagiaan dirinya dan orang lain. Sementara golongan yang kurang sehat secara mentalnya sangat luas, mulia dari yang paling ringan sampai dengan yang paling berat.Golongan yang kurang sehat merupakan golongan yang masuk kategori memiliki konflik batin. Gejala - gejala umum yang tergolong orang yang kurang sehat dapat dilihat dari beberapa aspek, antara lain:

1. Perasaan, gejala yang terjadi yakni memiliki perasaan yang terganggu, tidak tentram, gelisah, tetapi tidak tentu yang digelisahkan, dan tidak

9 Zakiah Daradjat, Pendidikan Agama dalam Pembinaan Mental, (Jakarta: Bulan Bintang, 1982), 38-39 pula dapat menghilangkannya atau anxiety ${ }^{10}$,rasa takut yang tidak masuk akal atau tidak jelas terhadap suatu objek, rasa iri, rasa sedih yang tidak beralasan, rasa rendah diri, sombong, suka bergantung kepada orang lain, tidak mau bertanggung jawab dan masih banyak lagi.

2. Pikiran, gangguan yang biasanya menyerang kesehatan mental salah satunya adalah gangguan di pikiran. Misalnya, anak - anak menjadi bodoh di sekolah, pemalas, pelupa, suka membolos, tidak dapat berkonsentrasi dan masih banyak lagi. Demikian pula, irang dewasa yang merasa kurang mampu melanjutkan sesuatu yang telah direncanakannya baik - baik, mudah dipegaruhi orang lain, menjadi pemalas, apatis dan masih banyak lagi.

3. Kelakuan, dalam hal kelakuan pada umumnya biasanya yang sering terjadi adalah kenakalan, keras kepala, suka berdusta, menipu, menyeleweng, mencuri, menyiksa orang lain, membunuh, merampok dan menyebabkan orang lain menderita, hak teraniaya, termasuk pula akibat dari keadaan mental yang terganggun kesehatannya.

4. Kesehatan, yang dimaksud dengan gangguan kesehatan disini adalah jasmaninya terganggu bukan karena adanya penyakit yang betul - betul mengenai jasmani itu, sakit akibat dari jiwa yang tidak tentram. Penyakit dengan jenis ini disebut dengan psyco-somatic. Gejala dari penyakit ini antara lain adalah sakit kepala, merasa lemas, letih, sering masuk angin, tekanan darah tinggi atau rendah, jantung, sesak napas,

${ }^{1010}$ Prof. Dr. M. Solihin M.Ag dan Prof Dr. Rosihon Anwar, M.Ag, Op. Cit, 107 
sering pingsan (kejang), bahkan sampai sakit yang lebih berat yakni lumpuh sebagian anggota badan, lidah keluh dan sebagainya. Yang penting adalah penyakit jasmani ini tidak mempunyai sebab - sebab fisik sama sekali. ${ }^{11}$

Berbagai penyakit diatas akan timbul dengan sendirinya pada diri manusia yang hatinya tidak tenang, yakni hati yang jauh dari Tuhannya. Keadaan semacam demikian akan memicu munculnya penyakit mental atau konflik batin pada diri manusia, yang pada gilirannya akan menjelma menjadi perilaku yang tidak baikdan menyeleweng dari norma norma umum yang disepakati.

c. Implementasi Tasawuf sebagai Psikoterapi dalam Mengatasi Konflik Batin

Ilmu tasawuf merupakan sikap mental yang selalu memelihara kesucian diri, beribadah, hidup sederhana, rela berkorban untuk kebaikan dan selalu bersikap bijaksana. Dalam pengertian lain tasawuf merupakan upaya melatif jiwa dengan berbagi kegiatan yang dapat membebaskan dirinya dari pengaruh kehidupan dunia, sehingga tercermin akhlaq mulia dan dekat dengan Allah SWT. ${ }^{12}$ Di dalam ilmu psikoterapi tingkah laku manusia sebagai anggota masyarakat dinilai sebagai manifestasi dan aktivitas rohaniah, terutama yang ada hubungannya dengan tingkah laku, baik itu di dalam maupun di luar kelompoknya, juga interaksi antara yang satu dengan yang lainnya di masyarakat.

Setiap perilaku manusia di dasarkan pada kehendak dari manusia itu.Apa yang telah dilakukan oleh manusia timbul dari kejiwaannya. Walaupun pancaindera kesulitan melihat pada dasar kejiwaan, namun dapat dilihat dari wujud kelakuan.

Konflik batin merupakan konflik yang tersembunyi yang berada pada batin manusia atau sering disebut sebagai intrapsychic. Untuk mengatasi adanya konflik batin diperlukan suatu metode yang di dalamnya mengandung dorongan untuk berusaha meningkatkan pengertian diri sendiri yang tersembunyi dan dengan begitu akan menghasilakn berbagai perubahan pada batin manusia.Konflik batin terjadi dikarenakan terganggunya hubungan atara dua orang atau dua kelompok, perbuatan yang satu berlawanan dengan perbuatan yang lain sehingga salah satu dari keduanya merasa saling terganggu. Beberapa hal yang sering menyebabkan adanya konflik batin anatara lain:

1. Agresi, yakni menunjukkan bahwa konflik terjadi karena perasaan marah yang ditunjukkan kepada diri sendiri.

2. Kehilangan, merujuk pada perpisahan traumatik individu terhadap suatu benda atau seseorang yang sangat berarti.

3. Kepribadian, menguraikan bagaimana konsep diri yang negatif dan harga diri rendah mempengaruhi sistem keyakinan dan penilaian terhadap faktor pencetus konflik.

4. Kognitif, depresi merupakan masalah kognitif yang didominasi oleh evaluasi negatif seseorang terhadap dirinya, dunia seseorang dan masa depannya.

5. Ketidak berdayaan, trauma bukanlah satu - satunya faktor menyebabkan masalah tetapi keyakinan bahwa seseorang tidak mempunyai kendaliterhadap hasil yang penting dalam kehidupannya.

6. Perilaku, perkembangan dari kerangka teori belajar sosial bahwa

\footnotetext{
${ }^{11}$ Zakiah Daradjat, Op. Cit, 38 - 41
} 
penyebab terjadinya konflik dalam diri terletak pada kurangnya keinginan positif dalam berinteraksi dengan lingkungan.

7. Perbedaan individu yang meliputi perbedaan pendirian dan perasaan.

8. Perbedaan latar belakang kebudayaan sehingga membentuk pribadi - pribadi yang berbeda.

9. Perbedaan kepentingan antara individu atau kelompok.

Perubahan - perubahan nilai yang cepat dan mendadak dalam masyarakat.Dari konflik diatas ada cara dalam mengedalikannya yakni:

1. Mengidentifikasi jenis - jenis konflik yang terjadi, artinya berusaha mengenali jenis konflik apa yang sedang dialami, konflik pribadi, keluarga, dengan teman, dengan sekolah dan seterusnya.

2. Mencari sumber konflik, untuk mengetahui sumber konfliknya, setelah itu rumuskan sesuai dengan sumber - sumber yang diperoleh dengan penilaian secara objektif.

3. Mengatasi konflik, cara yang paling sederhana dalam mengatasi suatu konflik adalah melakukan intropeksi diri kemudian gunakan kekuatan daya pikir yang sehat.

Sudah sejak awal bahwa tasawuf bertujuan untuk mendekatkan diri kepada Tuhan.Akan tetapi, ini menunukkan betapakita pada saat ini masih jauh dari-Nya, karena perlu disdarai bahwa sekarang manusia hidup di perantauan jauh dari asal dan tempat kembali kita yang sejati.

Dari ajaran para sufi, manusia bukan hanya sebaga makhluk fisik, akan tetapi juga disebut sebagai makhluk spiritual. Dengan menyadari betapa manusia itu juga makhluk spiritual, maka tindakan

\footnotetext{
${ }^{13}$ Mulyadhi Kartanegara, Menyelami Lubuk Tasawuf, (Jakarta: Erlangga, 2006), 272
}

lebih bijak dan seimbang dalam memperlakukan diri sendiri sangat dibutuhkan. Dengan memperhatikan kesejahteraan, kebersihan dan kesehatan jiwa. $^{13}$

Dalam menjawab problema psikologis, tasawuf mengajarkan tentang hidup yang bahagia.Hidup bahagia haruslah hidup dengan sehat baik secara fisik maupun batin. Dengan hidup dengan bahagia maka konflik batin tidak akan pernah didapatkan. Hal ini dikarenakan kebahagiaan yang tercipta akan membuang secara keseluruhan pikiran - pikran yang bersifat batin.

Untuk menangani konflik batin, yang biasa dilakukan oleh para psikoterapis terhadap kliennya antara lain hipnoterapi, neurolinguistic program dan spiritual thinking. Sedangkan secara Islam teknik yang biasa digunakan adalah takholli, tahlli dan tajalli.Dengan metode semacam ini, diharapkan bagi seseorang dapat menemukan solusi atas permasalahannya.Hal ini sering disebut dengan self therapy atau penyembuhan atas dirinya sendiri. Akan tetapi untuk penggunaan teknik pada setiap implementasinya berbeda - beda, tergantung dari masalah yang dialami.

Selain beberapa metode diatas ada salah satu metode lagi yaitu metode komunikasi quanta atau yang biasa disebut dengan istilah telepati hati.Dalam fisika quantum, telah ditemukan bahwa dibalik semua yang ada di dunia (materi) sebenarnya hanyalah terdiri dari energy getaran (vibrasi) yang disebut dengan istilah quanta. ${ }^{14}$ Kesempurnaan manusa pada dasarnya merupakan rangkuman dari semua manifestasi dari quanta tersebut karena manusia memiliki sifat materi(dengan adanya tubuh fisik) dan

\footnotetext{
${ }^{14} \mathrm{http}$ //www.keajaibanhati.com/2012/08/spiritualmind-power-revolution.html diakses tgl. 29 Agustus 2016
} 
sifat yang lebih tinggi dan agung (divine atau Ilahiah) dalam jiwa dan ruhnya yang terwujud dalam pikiran dan perasaan manusia. Melalui kesadaran untuk manusia kembali kepada fitrahnya, yaitu kembali kepada sifat dan kecenderungan ilahiahnya.Oleh sebab itu, manusia bergerak menuju suatu tingkatan kesadaran yang semakin tinggi dan pada akhirnya berada dalam posisi parallel atau selaras dengan sumber materi yang lebih tinggi tersebut.Seandainya keselarasan itu terjadi, maka hal yang ada dalam alam materi dunia bisa terwujud.

\section{CATATAN AKHIR}

Adapunmacam-macam penyakit jiwa menurut Dadang Hawari antara lain:

- Fobia,yaitu rasa takut yang tidak rasional dan tidak realistis. Pengidapnya tahu dan sadar benar akan ketidakrasionalan dan ketidakbenarannya,tetapi ia tidak mampu mencegah dan mengendalikan diri dari rasa takut tersebut.

- Obsesi,yaitu corak pikiran yang sifatnya terpaku dan berulang kali muncul. Orang yang mengalami gangguan ini tahu akan kelainan pikirannya itu, tetapi tidak mampu mengalihkan pikirannya kemasalah lain dan tidak mampu mencegah munculnya pikiran tersebut yang selalu muncul berulang- ulang.

- Kompulsi, yaitu pola perbuatan yang diulang-ulang. Pengidapnya paham benar bahwa perbuatan mengulangulang itu tidak benar dan tidak rasional,tetapi ia tidak mampu mencegah perbuatannya sendiri.

Peranan dari pandangan kaum sufi, akhlak dan sifat seseorang bergantung pada jenis jiwa yang berkuasa atas dirinya. Jika yang berkuasa dalam tubuhnya adalah nafsu- nafsu hewani atau nabati yang akan tampil dalam perilakunya adalah perilaku hewani atau nabati pula. Sebaliknya, jika yang berkuasa adalah nafsu insani,yang akan tampil perilakunya adalah insani pula

Untuk menjawab problema psikologis, tasawuf mengajarkan tentang hidup yang bahagia. Hidup bahagia haruslah hidup dengan sehat baik secara fisik maupun batin. Dengan hidup dengan bahagia maka konflik batin tidakakan pernah didapatkan. Hal ini dikarenakan kebahagiaan yang terciptaakan membuang secara keseluruhan pikiran - pikran yang bersifat batin.

\section{DAFTAR PUSTAKA}

AfifudindanBeni Ahmad Saebani. 2009. Metodologi Penelitian Kualitatif. Bandung: PustakaSetia.

Alishah, Omar. 2002. Tasawuf sebagai Terapi. Bandung: Pustaka Hidayah.

Al-Taftazani, Abu Al Wafa Al-Ghanimi. 1997. Sufi dari Zaman KeZaman. Bandung: Pustaka,

Alwi, Hasan. 2005. Kamus Besar Bahasa Indonesia. Jakarta: Balai Pustaka.

Annajar, Amin. 2004. Psikoterapi Sufistik dalam Kehidupan Modern. Bandung: Mizan Media Utama.

Arifin, Isep Zainal.2009. Bimbingan Penyuluhan Islam, Pengembangan Dakwah Melalui Psikoterapi Islam. Jakarta: PT. Raja Grafindo Persada.

KArtanegara, Mulyadi. 2006. Menyelami Lubuk Tasawuf. Jakarta: Erlangga

Moleong, Lexy. 1990. Metodologi Penelitian Kualitatif. Bandung: Pustaka.

Nata, Abuddin. 2010. Akhlaq Tasawuf. Jakarta: PT. Raja Grafindo

Nuriyah, Fasikhatun. 2008. Tasawuf Sebagai Terapi Atas Problem Psikologis Manusia Menurut Omar Alishah dalam Bukunya "Tasawuf Sebagai Terapi” (Perspektif Bimbingan Konseling Islam). Semarang: Fakultas Dakwah IAIN Walisongo. 
Solihin dan Rosihon Anwar. 2008. Ilmu Tasawuf. Bandung: Pustaka Setia

Riyadi, Agus. 2005. Konsep Dzikir Menurut Al Qur'an sebagai Terapi Penderita Psikoneurotik (Analisis Bimbingan Konseling Islam). Semarang: Fakultas Dakwah IAIN Walisongo.

Soleh, Moh. 2005. Agama Sebagai Terapi. Yogyakarta: Pustaka Pelajar.

Syukur, M. Amin. 2003. Tasawuf Kontekstual Solusi Problem Manusia Modern. Yogyakarta: Pustaka.

Sugiono. 2010. Metode Penelitian Pendidikan Pendekatan Kuantitatif, Kualitatif, dan R\&D. Bandung: Pestaka Setia.

Zakiah Daradjat. 1982. Pendidikan Agama dalam Pembinaan Mental. Jakarta: Bulan Bintang

http://id.wikipedia.org/wiki/Psikoterapi

http://www.keajaibanhati.com/2012/08/spi ritual-mind-powerrevolution.htmldiaksestgl. Agustus 2016 